\title{
PERSEPSI KADER TERHADAP PROGRAM GERAKAN 1 RUMAH 1 JUMANTIK (G1R1J) DALAM PENGENDALIAN DEMAM BERDARAH DENGUE DI KELURAHAN PONDOK BETUNG KOTA TANGERANG SELATAN
}

\section{Cadres Perceived of One House One Jumantik (G1R1J) Program on Dengue Control in Pondok Betung Sub District Tangerang Selatan}

\author{
Yuneu Yuliasih, M. Ezza Azmi Fuadiyah, Rohmansyah Wahyu Nurindra, Arda Dinata, Heni Prasetyowati, Mara Ipa \\ Loka Litbangkes Pangandaran-Badan Litbang Kesehatan
}

Naskah masuk: 18 Juni 2020 Perbaikan: 27 Agustus 2020 Layak terbit: 27 November 2020

https://doi.org/10.22435/hsr.v23i4.3338

\begin{abstract}
ABSTRAK
Program Gerakan 1 Rumah 1 Jumantik (G1R1J) adalah satu upaya pemberdayaan masyarakat dalam pelaksanaan pemberantasan sarang nyamuk Demam Berdarah Dengue (DBD). Program tersebut melibatkan salah satu anggota keluarga menjadi jumantik rumah. Salah satu faktor yang memengaruhi perilaku masyarakat dalam pelaksanaan suatu program adalah adanya faktor pendorong berupa sikap dan perilaku tokoh, petugas kesehatan atau petugas lain yang merupakan kelompok referensi masyarakat. Tujuan penelitian ini adalah mengetahui persepsi kader terhadap Program G1R1J, sebagai agen perubahan dalam pengendalian DBD dan perannya di masyarakat. Penelitian ini merupakan penelitian kualitatif dengan pendekatan Health Belief Model (HBM). Pengumpulan data dilakukan pada tahun 2019 melalui Diskusi Kelompok Terarah (DKT) dan wawancara mendalam (In-Depth Interview/IDI). Informan penelitian ini adalah kader yang berada di Kelurahan Pondok Betung Kecamatan Pondok Aren yang merupakan wilayah endemis DBD di Kota Tangerang Selatan. Data yang diperoleh kemudian diolah berdasar analisis tematik. Hasil penelitian menunjukkan bahwa kader sebagai ujung tombak implementasi program G1R1J sudah memiliki pemahaman yang baik tentang teknis program di masyarakat. Persepsi risiko terkait penyakit dan manfaat dari program G1R1J menjadi salah satu motivasi kader dalam menjalankan perannya. Kurangnya respon dan ketergantungan masyarakat terhadap kader menjadi hambatan dalam pelaksanaan program G1R1J. Upaya yang dapat dilakukan adalah sosialisasi program GIRIJ di tingkat keluarga dengan melibatkan lintas sektor.
\end{abstract}

Kata Kunci: Persepsi, kader, Gerakan 1 Rumah 1 Jumantik, DBD, Tangerang Selatan

\begin{abstract}
Program of One House One Jumantik (or G1R1J) is a community empowerment endeavor to eradicate mosquito nest of Dengue Hemorrhagic Fever. Program involves one of the family members to be a Larvae Monitoring Specialist at home. Factors influencing community behavior to implement a program are driving factors such as attitudes, and community leader's behavior, health staff, and other health staff that is a community reference group. The study's objective is to know the cadres' perception of the G1R1J Program as an agent of change to control DHF and their roles in a community. A qualitative study with Health Believe Model Approach. Data Collection conducted in the year 2019 using Focus Group Discussion and In-Depth Interview methods. Informants are cadres in Pondok Betung Sub-District Pondok Aren District, which a DBD endemic area in South Tangerang City. Data obtained were then processed according to thematic analysis. The study results showed cadre as a frontline implementation of G1R1J Program, who have a good understanding concerning program technical in Community. Risk perception related to disease and benefit from G1R1J Program is one of cadre motivation to run roles. Lack of response and dependency of the community about cadre are obstacles to conduct G1R1J Program. Efforts can do socialization of the G1R1J Program at the family level, which involves across sectors.
\end{abstract}

Keywords: Perception, Cadre, G1R1J, DHF, South Tangerang City

\footnotetext{
Korespondensi:

Yuneu Yuliasih

Loka Litbangkes Pangandaran-Badan Litbang Kesehatan
}

E-mail: yuneu.y@gmail.com 


\section{PENDAHULUAN}

Demam Berdarah Dengue (DBD) saat ini sudah menyebar luas ke berbagai wilayah dunia. Pada tahun 1970, kasus DBD hanya ditemukan di sembilan negara. Namun, saat ini lebih dari 100 negara di Afrika, Mediterania Timur, Amerika, Asia Tenggara, dan Pasifik Barat menjadi daerah endemis DBD. Sekitar 3,9 miliar orang di 128 negara beresiko terinfeksi virus dengue (Brady et al., 2012). Sekitar 500.000 orang dirawat di rumah sakit karena DBD setiap tahunnya dan 2,5\% kasus DBD berakhir dengan kematian (WHO, 2017).

Sejak pertama kali ditemukan di Surabaya dan Jakarta pada 1968, kasus DBD makin luas persebarannya di Indonesia dengan jumlah kasus yang masih berfluktuasi (Astuti and Yuliasih, 2019). Pada periode 2010-2017 jumlah kasus DBD di Indonesia secara keseluruhan tercatat sebanyak 1.213.324 penderita dengan rata-rata Incidence Rate (IR) adalah 49,55 per 100.000 penduduk. Seluruh provinsi melaporkan adanya kasus DBD, kecuali tahun 2011. Pada tahun tersebut, Papua dan Papua Barat tidak melaporkan adanya kasus DBD. (Kementerian Kesehatan Republik Indonesia, 2018).

Kejadian DBD di Provinsi Banten pada Tahun 2017 memiliki IR sebesar 11,59 dengan CFR 0,79\%. Incidence Rate DBD di wilayah Provinsi Banten mengalami penurunan sedikit pada Tahun 2018 yaitu sebesar 11,48 dengan CFR $0,86 \%$. Salah satu wilayah penyumbang kasus DBD di wilayah Provinsi Banten adalah Kota Tangerang Selatan. Kasus DBD seluruh wilayah kecamatan di Kota Tangerang Selatan pada periode 2016-2018 berfluktuasi. Pada Tahun 2016 IR DBD Kota Tangerang Selatan sebesar 42,44 per 100.000 penduduk. Angka ini menurun tajam pada tahun 2017 menjadi 15,94. Namun, setelah tahun 2017, IR DBD Kota Tangerang selatan bergerak naik kembali pada tahun 2018 yaitu 28,53 (Dinas Kesehatan Provinsi Banten, 2019).

Pengendalian DBD telah diatur dalam Keputusan Menteri Kesehatan RI No. 92 Tahun 1994 dengan menitikberatkan pada upaya pencegahan dengan gerakan Pemberantasan Sarang Nyamuk (PSN) (Kementerian Kesehatan Republik Indonesia, 2016). Pelaksanaan PSN sangat berkaitan dengan perilaku masyarakat sebagai pelaku utamanya. Salah satu upaya pemberdayaan masyarakat dalam pelaksanaan PSN yang digulirkan pemerintah adalah melalui Gerakan Satu Rumah Satu Jumantik (G1R1J) (Selviana and Suwarni, 2019). Gerakan tersebut merupakan strategi pengendalian DBD yang sangat penting karena melibatkan seluruh masyarakat hingga tingkat keluarga. Pelaksanaan pemantauan dan pemberantasan jentik nyamuk dalam keluarga (rumah) merupakan tanggung jawab keluarga itu sendiri dengan kepala keluarga atau salah satu anggota keluarga menjadi jumantik rumah. Selain jumantik rumah, ada peran jumantik lingkungan yang bertanggung jawab terhadap pemantauan dan pemberantasan di tempat umum dan tempat ibadah. Pembinaan jumantik rumah dan lingkungan dilakukan oleh koordinator jumantik yang biasanya merupakan kader kesehatan yang aktif di masyarakat. Kader kesehatan tersebut berasal dari masyarakat sendiri sehingga dapat lebih efektif dalam meningkatkan kesadaran masyarakat (Prasetyowati and Tim, 2019).

Seorang koordinator jumantik merupakan salah satu unsur penting dalam keberhasilan program G1R1J di masyarakat. Anjuran dari koordinator jumantik yang dalam hal ini adalah kader kesehatan dapat memengaruhi tindakan masyarakat untuk berpartisipasi dalam pemberantasan DBD. Koordinator jumantik seharusnya mendapat pembekalan pengetahuan dan keterampilan agar mereka mampu secara mandiri melakukan tugasnya dengan baik. Beberapa studi menyebutkan bahwa partisipasi kader di masyarakat dipengaruhi oleh motivasi, pengetahuan dan keterampilan teknis, keterampilan sosial, kemampuan perencanaan dan problem solving (kemampuan manajerial). Pengetahuan dan persepsi yang baik menjadikan kader mampu menyampaikan penyuluhan dengan baik (Djafar, 2014). Sikap kader yang positif akan berdampak pada kemauan kader untuk selalu proaktif dan bertanggung jawab dalam memberikan sosialisasi kepada masyarakat.

Studi ini bertujuan untuk mengetahui pengetahuan dan persepsi koordinator jumantik tentang gerakan satu rumah satu jumantik dalam rangka pencegahan DBD di wilayah Keluarahan Pondok Betung, Kota Tangerang Selatan. Pendekatan yang dilakukan dalam studi ini menggunakan kerangka Health Belief Model (HBM). Model ini memiliki kemampuan untuk menjelaskan dan memprediksi berbagai perilaku terkait outcome kesehatan positif (misalnya kesembuhan) (Carpenter, 2010). Selain itu, HBM memiliki tujuan awal untuk memfokuskan upaya peningkatan kesehatan masyarakat dengan memahami penyebab suatu tindakan pencegahan masalah kesehatan gagal diadopsi (Rosenstock, 1974). Penggunaan HBM sebagai kerangka kerja 
bertujuan untuk mengeksplorasi dan memahami perilaku pencegahan DBD dengan mengembangkan pemahaman mendalam tentang interaksi yang kompleks antara faktor psikologis, sosial, budaya, dan individu yang memunculkan perbedaan perilaku kesehatan terkait DBD. (Rosenstock, 1974).

\section{METODE}

Studi ini merupakan analisis lanjut dari penelitian "Riset Implementasi Model Juru Pembasmi Jentik (Jurbastik) dalam Penanggulangan DBD (Multicenter 2019)". Persetujuan etik diperoleh dari Komisi Etik Badan Penelitian dan Pengembangan Kesehatan Kemenkes RI No. LB.02.01/2/KE.296/2018. Lokasi penelitian di RW 02 Kelurahan Pondok Betung. Subyek sampel dalam penelitian ini adalah kader kesehatan di lokasi penelitian yang ditentukan secara purposive sampling. Pengumpulan data dilakukan melalui Diskusi Kelompok Terarah (DKT) dan wawancara mendalam (In-Depth Interview/IDI) pada Juni 2019. Diskusi Kelompok Terarah dilakukan dalam dua kelompok dengan peserta masing-masing kelompok berjumlah 8-10 orang kader.

Data yang diperoleh divalidasi melalui triangulasi sumber ke beberapa informan. Informan dalam kegiatan wawancara mendalam tidak hanya kader tetapi juga unsur stakeholder di level provinsi, kabupaten, puskesmas, dan juga tokoh masyarakat. Analisis data kualitatif dilakukan dengan analisis tematik (thematic analysis) dengan pendekatan deduksi. Beberapa peneliti melakukan koding terhadap masing-masing data hasil wawancara untuk menjaga konsistensi hasil. (Rubin and Rubin, 2012).
Analisis kualitatif dilakukan dengan menggunakan pendekatan HBM untuk menilai perspektif tentang DBD (Siddiqui et al., 2016). Tematik yang diteliti meliputi lima aspek yaitu (1) Pemahaman konsep penyakit, pengetahuan tentang penyebab, penularan, pencegahan dan pengendalian DBD; (2) keparahan yang dirasakan (perceived severity); (3) isyarat untuk melakukan tindakan (cues to action); (4) manfaat yang dirasakan (perceived benefits); dan (5) hambatan yang dirasakan (perceived barriers). (Rosenstock, 1974).

Pengetahuan mencakup tentang penyebab DBD, gejala DBD, cara penularan DBD serta cara pencegahan dan pemberantasan DBD. Peran tokoh masyarakat digali dari waktu dan bentuk kegiatan yang dilakukan di lingkungannya, faktor pendukung dan kendala yang dihadapi, serta pembinaan dari sektor kesehatan dan lintas sektor di luar kesehatan.

Pengukuran keparahan dilihat pada anggapan bahwa DBD bisa menyebabkan kematian, dan kerugian yang didapat, serta penilaian pada akibat yang ditimbulkan dari DBD. Cues to action berupa stimulus yang diperlukan untuk memicu proses pengambilan keputusan untuk menerima tindakan kesehatan yang direkomendasikan, meliputi internal (misal: komitmen, tanggung jawab) dan eksternal (misal: sosialiasi GIRIJ, dukungan tokoh masyarakat, pelatihan, insentif).

Perceived benefit yang dimaksud dalam penelitian ini adalah manfaat yang dirasakan masyarakat dengan adanya program G1R1J dengan keberadaan kader sebagai agen perubahan. Sedangkan persepsi hambatan menggambarkan beberapa kendala yang dirasa oleh subyek penelitian.

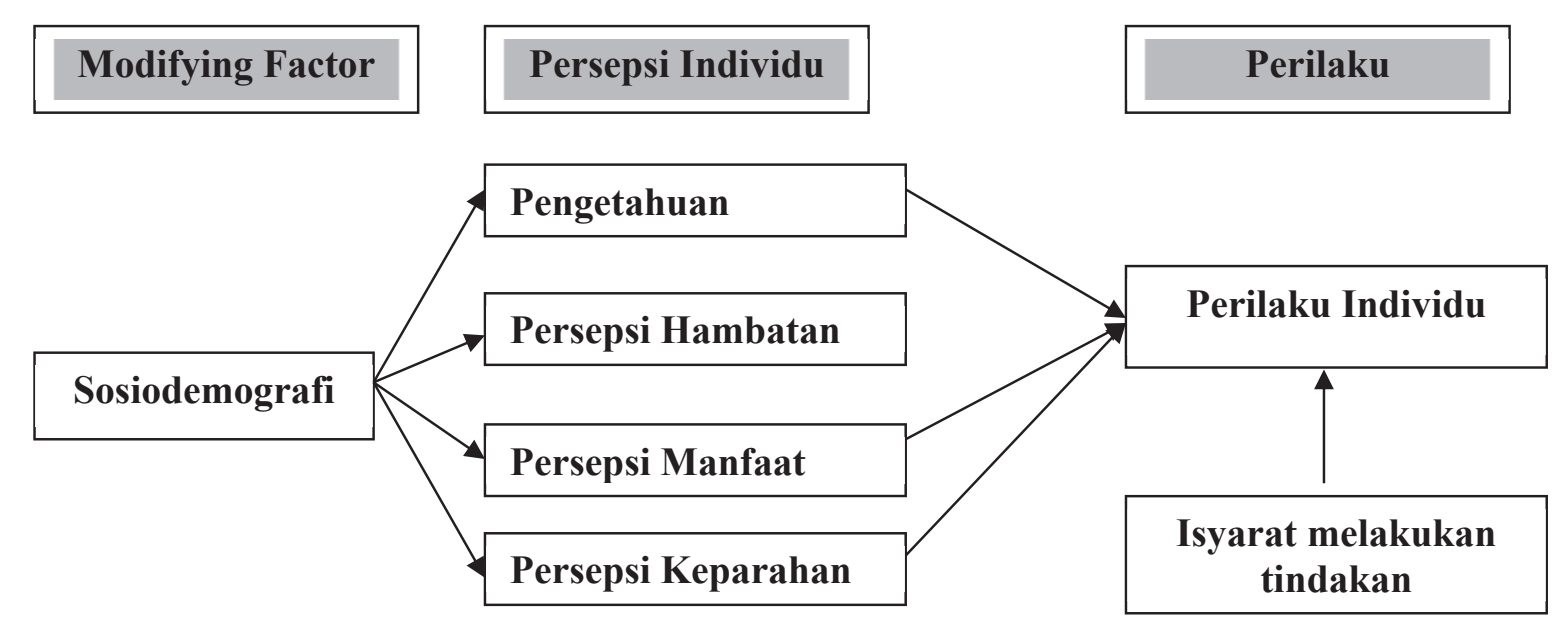

Gambar 1. Kerangka Health Belief Model 
HASIL

\section{Gambaran lokasi penelitian dan karakteristik kader}

Kelurahan Pondok Betung memiliki luas wilayah $4,7777 \mathrm{~km}^{2}$. Jumlah penduduk kelurahan tersebut sebanyak 64.476 jiwa yang terdiri dari 32.972 jiwa laki-laki dan 31.504 jiwa perempuan, dengan tingkat kepadatan penduduk rata-rata 13.495 jiwa per $\mathrm{km}^{2}$. Berdasarkan data kasus DBD selama Tahun 2019, tercatat 9 kasus DBD di Kelurahan Pondok Betung. Jumlah kasus tersebut mengalami peningkatan dari tahun 2018. (Prasetyowati and Tim, 2019)

Beberapa kegiatan dalam rangka pengendalian DBD telah dilakukan di wilayah ini, di antaranya berupa sosialisasi DBD, pelatihan kader jumantik, PSN, penerapan program G1R1J, pemberian larvasida (temephos), Pemantauan Jentik Berkala (PJB), sertifikasi RW bebas jentik dan silent survey. Subyek penelitian dalam penelitian ini adalah 20 orang kader yang bertindak sebagai koordinator juru pemantau jentik (jumantik) di Kelurahan Pondok Betung, Kecamatan Pondok Aren (Tabel 1).

Keseluruhan subyek penelitian adalah perempuan dan didominasi usia di atas 45 tahun yaitu sebanyak $63 \%$. Sebagian besar mempunyai pengalaman sebagai kader selama kurang dari 2 tahun (84\%) dengan mayoritas merupakan lulusan pendidikan menengah (53\%).

\section{Pengetahuan DBD dan Pemahaman Konsep Gerakan 1 Rumah 1 Jumantik (G1R1J)}

Berdasarkan hasil wawancara mendalam dan DKT terhadap 20 informan, sebagian besar informan sudah dapat menjelaskan tentang DBD. Meskipun demikian, tidak semua dapat menjelaskan secara komprehensif.

Tabel 1. Karakteristik kader juru pembasmi jentik (Jurbastik) DBD sebagai agen perubahan di Kota Tangerang Selatan Tahun 2019

\begin{tabular}{lcc}
\hline Karakteristik & $\mathbf{n}$ & \% \\
\hline Usia & & \\
$\quad<=45$ tahun & 7 & 37 \\
$\quad>45$ tahun & 12 & 63 \\
$\quad$ Masa kerja menjadi kader & & \\
$\quad<=2$ tahun & 16 & 84 \\
$\quad>2$ tahun & 3 & 16 \\
Pendidikan & & \\
$\quad$ Dasar & 7 & 37 \\
$\quad$ Menengah & 10 & 53 \\
$\quad$ Lanjutan & 2 & 10 \\
\hline
\end{tabular}

"Penyakit Demam berdarah yang menular, yang disebabkan oleh nyamuk yang membawa virus, dibawa dari orang yang sakit kemudian menggigit orang yang sehat." (Koordinator Jumantik 9, 40 tahun).

Ada satu informan yang dapat menjelaskan mulai penyebab, penularan, gejala, pemeriksaan uji dan upaya pencegahan yang dilakukan. Berikut informasi yang diuraikan:

"Yang pertama ya, yang pasti demam berdarah itu adalah penyakit yang ditularkan oleh nyamuk, nyamuknya itu adalah nyamuk Aedes aegypti.. dia bisa menggigit kepada orang yang sehat, yang kemudian imun di dalam tubuhnya berkurang, makanya dia terkena...gejalanya demam, yang kedua badannya bintik-bintik, terus kalau dulu 3 hari kalau sekarang lebihcanggih, 2 sampai dengan 3 hari itu sudah bisa terlihat, kemudian ..eeuh...badannya panas ya bu ya... badannya panas, kemudian dia agak mual, terus dia juga harus banyak minum ketika dia terkena demam berdarah, bagaimana dia terdekteksi demam berdarah?dengan cara lab, kalau tidak lab, kita tidak bisa memastikan dia terkena $D B$, penanggulangannya yaitu dengan cara membersihkan rumah terutama yang ada genangan airnya, di ember, di bak, di vas bunga, di penampungan air, di tempat minum burung, kemudian diatas talang, terus itu dibersihkan minimal seminggu sekali ya." (Koordinator Jumantik 2, 44 tahun).

Pemahaman tentang program pengendalian DBD gerakan satu rumah satu jumantik (G1R1J), hanya sebagian kecil informan yang dapat menjelaskan baik dari aspek substansi dan jumlah informan yang dapat menjelaskan, bahwa GIRIJ adalah salah satu program pengendalian DBD dengan pendekatan pemberdayaan masyarakat. Bahkan ada informan yang menyatakan tidak ada program G1R1J.

"Programnya ga ada ya ..cuman kita sering sosialisasi aja ke warga untuk membersihkan. menjaga lingkungan ...itu aja sih." (Koordinator Jumantik 7, 48 tahun).

"Program pemerintah, seperti kegiatan menimbun, menguras, bersih-bersih kamar mandi, pot pot di rumah, kalau menurut saya satu rumah satu jumantik itu lebih memberi tanggung jawab kepada pemilik rumah supaya menjaga 
kebersihan lingkungan di sekitar rumahnya sendiri." (Koordinator Jumantik 5, 49 tahun).

"Ya itu... setiap rumah harus memberantas jentik masing-masing, setiap mengontrol rumah-rumah kita ngasih tau...bu bahwa setiap rumah harus ada yang bertanggung jawab atau bertugas untuk pemeriksaan jentik, kita tinggal mengontrol saja. . gitu." (Koordinator Jumantik 1, 64 tahun).

\section{Keparahan (Perceived Severity) Risiko DBD}

Persepsi tingkat keparahan yang diakibatkan oleh DBD yang dinyatakan oleh subyek penelitian sangat beragam, mulai dari tingkat rendah sampai yang paling parah. Berikut penuturannya :

"Ya, sejauh ini saya seperti itu saja yaa, bahwa $D B D$ adalah penyakit yang berbahaya, yang disebabkan oleh nyamuk Aedes aegepty, itu saja." (Koordinator Jumantik 4, 35 tahun).

"Kalau yang namanya demam berdarah, semua berbahaya...karena dapat mengakibatkan kematian." (Koordinator Jumantik 11, 38 tahun).

"Pokoknya kalau sampe sudah parah, bisa halusinasi bisa mimisan, bisa muntah, itu pencegahannya harus minum banyak air." (Koordinator Jumantik 12,54 tahun).

\section{Tindakan (Cues to action) Pencegahan DBD}

Stimulus untuk melakukan tindakan (Cues to action) berupa faktor internal dan eksternal dari informan dalam menjalankan tugas sebagai agen perubahan. Faktor eksternal di antaranya adanya undangan untuk berpartisipasi pada sosialisasi program GIRIJ dalam bentuk pelatihan. Namun hanya beberapa informan koordinator jumantik saja yang mendapatkan kesempatan tersebut.

"Jadi begini ibu untuk sosialisasi G1R1J, karena ini posyandu...biasanya diambil satu untuk perwakilan, kemudian kita sebagai kadernya ini mensosialisasikan ke RT masing-masing, jadi untuk yang mendapatkan langsung dari puskesmas karena itu terbatas secara jumlahnya, karena perwakilan." (Koordinator Jumantik 2, 44 tahun).

"Gini ya, kita kan koordinator setelah mendapatkan informasi dari puskesmas maka kita langsung mengumpulkan kader untuk mensosialisasikan tentang G1R1J." (Koordinator Jumantik 5, 49 tahun).
"Sebenarnya untuk satu rumah satu jumantik sebelum tahu litbangkes kita sudah tahu dari puskesmas, bahwa pemahaman secara umum kita di beri tahu, tetapi tidak secara khusus, tetapi tidak semua, hanya beberapa orang... kita yang pertama di beri tahu bertugas untuk menularkan...hehehe..menularkan kepada yang lainnya, memberikan informasi kepada temanteman yang lain, terus yang kedua itu bersama dengan Litbang, kalau yang dengan litbang itu kita bersama-sama dengan warga, jadi ada kaderkader yang datang ada juga warga yang datang." (Koordinator Jumantik 14, 55 tahun).

Kegiatan sosialisasi terkait program GIRIJ telah disampaikan oleh Kepala Puskesmas serta pemegang program DBD di tingkat Puskesmas dan Dinas Kesehatan Kota Tangerang Selatan, meskipun belum optimal implementasinya.

"lya, jadi kita tetap dengan dibantu puskesmas baik dinas kita melakukan sosialisasi pelatihan, uji coba sampai dengan pelaksanaan." (Pengelola Program DBD, 35 tahun).

"Setelah kita melaksanakan sosialisasi, dan disepakati program setiap RT menunjuk supervisor...eeh, 1 supervisor itu berada di RW, jadi 1 RT 1 koordinator, di RW ada 1 supervisor... akhirnya terbentuklah, nah disetiap RT itu pak, di bawah koordinator ada lagi 10 orang untuk membantu tugas koordinator...sekarang ini di RW 2 ini, dengan adanya 11 RT pak, ada 110 orang." (Kepala Puskesmas, 50 tahun).

Dukungan dari puskesmas sebagai stakeholder dan tokoh di lingkungan wilayah kerja, seperti RT dan $\mathrm{RW}$, juga menjadi motivasi dalam menjalankan tugas sebagai koordinator jumantik.

"Puskesmas mendukung sih yang pasti... cukup bagus, dengan melakukan sosialisasi... penyuluhan...kecamatan sampai saat ini belum sih mungkin pada saat kemarin saja baru datang ketika dilakukan sosialisasi."(SM, 44 tahun).

"Kalau dukungan pasti ada ya bu, contohnya kita dikasih senter dari RT walaupun itu cuma dipinjemin sih bu, trus kalo habis kita jumantik kumpul kumpul ada makan biaya dari pak RT seperti itu lah bu ...... Dukungan pak RT: lya ada itu senter juga biayanya juga dari pak RT." (Koordinator Jumantik 14, 45 tahun). 
Faktor internal yang melatarbelakangi para kader bersedia sebagai agen perubahan pengendalian DBD di lingkungannya adalah semata-mata karena kesadaran sebagai bentuk pengabdian pada masyarakat.

"Kalau kader jumantik selama ini tidak ada, jadi kita hanya swadaya aja kita sendiri..terutama pak RT, hanya itu saja bu...sebenarnya kita juga kepingin ...maaf ya...kayak DKI kader jumantik pun dapat insentif, kan beda ya kader kesehatan dengan kader jumantik...kalau kader kesehatan sudah ada dari ibu wali..sampai saat ini belum ada, masih pure (eng: murni)...kita gotongroyong...dan memang bekerja secara sosial, ya kalau syukur-syukur kalau ada itu tambah motivasi kita..semangat kita, tapi bukan karena materi bukan karena duitnya ya...tapi memang kita sebagai warga ada rasa tanggung jawab, karena kita semua ini kan berkerja secara sosial." (Koordinator Jumantik 14, 45 tahun).

"Insya Alloh ya...kalo saya pikir kalo ngga kita siapa lagi..soalnya kan ini kalo di bilang kerja sukarela ya sukarela kalo ngga ada salah satu yang mau akan seperti apa gitu Iho." (Koordinator Jumantik 20, 53 tahun).

\section{Manfaat (Perceived Benefits) Terhadap Tindakan Pencegahan DBD}

Persepsi manfaat yang dirasakan (Perceived Benefits) dipotret dari masyarakat sebagai jumantik rumah yang merupakan sasaran koordinator jumantik di program G1R1J dalam menjalankan perannya sebagai agen perubahan. Hasil menggali informasi kepada jumantik rumah keseluruhan menyatakan banyak manfaat terkait program G1R1J DBD, diantaranya ada yang membandingkan dengan upaya pengendalian pemberantasan sarang nyamuk (PSN) dengan fogging.

"Manfaat PSN dibanding fogging : ya lebih baik ini sendiri aja ya..kita bersihkan, yang kita bisa yang di rumah ini sendiri aja kita bersihkan. Alhamdulillah ya, kayaknya nggak ada deh yang kena itu..demam berdarah ini. tahun-tahun ini di sini...alhamdulillah nggak ada. Ya bermanfaat juga....Supaya rumah kita sering di tinjau diperiksa gitu supaya bersih supaya sehat." (Jumantik Rumah 1, 65 tahun).

Informan jumantik rumah lainnya menyatakan manfaat program G1R1J dalam menurunkan kasus DBD di wilayahnya.
"Bermanfaat sekali kalo ngga ada itu sangat banyak yang kena demam berdarah ...bagus itu terobosan dari kemenkes." (Jumantik Rumah 2, 34 tahun).

Jumantik rumah juga menyarankan agar koordinator jumantik juga melakukan upaya promosi kesehatan saat menjalankan tugasnya melaksanakan pemantauan.

"Selain kader datang mengunjungi warga untuk memantau hasil pemeriksaan jumantik rumah, perlu dilakukan sosialisasi/ngobrol tentang kegiatan tersebut. selain itu, kebersihan rumah juga perlu dipantau oleh kader sehingga masyarakat lebih peduli tentang kebersihan dan kesehatan di rumah masing-masing."(Jumantik Rumah 4, 55 tahun).

\section{Hambatan (Perceived Barriers) Terkait Pengendalian DBD}

Setiap pelaksanaan upaya program pengendalian tentunya ada hambatan yang dihadapi oleh para koordinator jumantik dalam menjalankan peran dan tanggung jawabnya. Adapun hambatan yang dirasakan (perceived barriers) menggambarkan berat ringannya implementasi program G1R1J. Beberapa kendala yang dirasakan adalah adanya penolakan dari masyarakat saat menjalankan tugas sebagai koordinator jumantik.

"Ya kalau penghambat sedikitlah ga banyak, ada beberapa rumahnya yang ga mau dimasukin karena belum beres-beres." (Koordinator Jumantik 2, 44 tahun).

"Saya bilang aja...ya udah kalau ga mau jangan sampai nanti ada jentiknya ya..heheh...ga apaapa ga mau dimasukin, nti kalau sewaktu-waktu ada jentiknya buang sendiri aja, saya ga pernah macem-macem, paling kalau ada yang ga mau saya laporkan ke pak RT." (Koordinator Jumantik 5, 49 tahun).

Selain itu, hambatan juga berupa respon masyarakat yang kurang terhadap upaya PSN dalam program G1R1J dan ketergantungan pada keberadaan koordinator jumantik.

"Hambatan muncul dari masyarakat yang kurang responsif ketika dikunjungi atau cuek dengan program G1R1J sehingga menyulitkan koordinator dalam pencatatan. Beberapa masyarakat sering lupa juga untuk mencatat hasil pemantauan yang mereka lakukan di form jentik dan seringnya yang 
mengisi adalah kader/koordinator." (Koordinator Jumantik 2, 44 tahun).

\section{PEMBAHASAN}

Persepsi kader terhadap program G1R1J dalam penelitian ini sangat bervariasi. Kondisi ini terkait erat salah satunya dengan pengetahuan informan yang belum komprehensif tentang penyakit DBD. Hal ini dapat dijelaskan bahwa tingkat pengetahuan seseorang memengaruhi perilakunya dalam mencegah penularan penyakit DBD.

Model pengetahuan-sikap-perilaku menganggap bahwa pengetahuan sangat penting untuk memengaruhi perubahan perilaku, dan bahwa individu dapat memperoleh pengetahuan dan keterampilan melalui pembelajaran (Li Liu et al., 2016). Sejalan dengan hasil penelitian di Denpasar yang menunjukkan kondisi masyarakat dengan tingkat pengetahuan rendah memiliki risiko terkena DBD sebesar 2,72 kali dibandingkan dengan masyarakat yang berpendidikan tinggi (Purnama, Satoto and Prabandari, 2013).

Namun demikian, adanya kecenderungan masyarakat untuk tidak menyerap seluruh informasi yang didapat, perlu mendapat perhatian. Fenomena ini terkait dengan tingkat motivasi dan pandangan setiap individu dalam menanggapi sebuah informasi. Saat individu tidak merasakan adanya manfaat dari suatu informasi, maka informasi tersebut cenderung dilupakan (Rasjid, Yudhastuti and Notobroto, 2016).

Pendekatan model HBM, menjadi dasar dalam melihat persepsi kader terhadap program Gerakan 1 Rumah 1 Jumantik (G1R1J) di Kota Tangerang Selatan, Provinsi Banten. Model kepercayaan kesehatan ini menggambarkan adanya pertimbangan seseorang sebelum berperilaku sehat (Burke, 2015). Sesuai dengan yang dilaporkan dalam penelitian di Kenya bahwa persepsi keparahan sering berdasarkan informasi kedokteran atau pengetahuan lain (Chepkemoi Ng'etich Mutulei, 2013).

Pemahaman derajat keparahan DBD yang beragam tergantung dari pengetahuan dan pengalaman yang dimiliki oleh seseorang. Sesuai dengan hasil penelitian (Attamimy and Qomaruddin, 2018) menyebutkan faktor persepsi keparahan penyakit DBD mempunyai hubungan dengan upaya pencegahan DBD yang dilakukan subyek penelitian. Artinya, jika persepsi kerentanannya tinggi, maka akan semakin besar upaya pencegahan DBD yang dilakukan. Begitu sebaliknya, jika semakin kecil penilaian pada persepsi keparahan, maka semakin buruk upaya pencegahan DBD yang dilakukan.

Penyuluhan dan pemberdayaan yang tepat pada masyarakat berdampak pada keberhasilan program. Hal ini, dibuktikan dari temuan penelitian bahwa intervensi pemberdayaan masyarakat menunjukkan peningkatan signifikan pada pengetahuan kesehatan (Sansiritaweesook G, 2015). Pengetahuan kesehatan yang meningkat menyebabkan masyarakat mudah memahami program yang sedang dilaksanakan.

Keikutsertaan masyarakat dalam program kesehatan, selain sosialisasi juga perlu ditumbuhkan kepercayaan dari hubungan yang terbentuk. Beberapa hasil studi melaporkan keberhasilan penerapan proses kemitraan dalam sebuah intervensi pemberdayaan masyarakat (HaldaneV, Chuah FLH, Srivastava A, Singh SR, Koh GCH, Seng CK, 2019). Hasil penelitian membuktikan bahwa keberadaan penyuluhan kesehatan rutin yang dilakukan puskesmas merupakan salah satu faktor yang berkorelasi terhadap penurunan kejadian DBD di sekolah dasar (Kartini and Martini, 2018). Demikian juga di tingkat keluarga, untuk menurunkan terjadinya kasus infeksi dengue diperlukan promosi kesehatan terhadap keluarga sehingga pengetahuan, sikap, dan perilaku masyarakat dapat ditingkatkan.

Substansi program G1R1J adalah pemberdayaan anggota keluarga sebagai jumantik yang sebelumnya peran tersebut diemban oleh kader. Pelimpahan tugas kepada jumantik rumah belum paripurna terkait adanya kesenjangan antara kader dan jumantik rumah. Sebagian jumantik rumah masih bergantung dan mengandalkan kader (koordinator jumantik) dalam melaksanakan PSN. Perbedaan peran pelaksanaan antara koordinator jumantik dengan jumantik rumah dapat disebabkan oleh faktor motivasi. Hasil penelitian (Djuhaeni, Gondodiputro and Suparman, 2010) menyebutkan kader memiliki motivasi internal dan eksternal dalam melaksanakan tugasnya. Motivasi internal yang paling berpengaruh ialah tanggung jawab, sedangkan motivasi eksternal yang paling berpengaruh ialah hubungan sosial. Motivasi inilah yang mungkin belum dimiliki oleh jumantik rumah untuk dapat melaksanakan tugasnya dengan baik.

Hasil penelitian menggambarkan implementasi program G1R1J di Kota Tangerang Selatan menghadapi beberapa hambatan yang terkait dengan peran keluarga sebagai jumantik, diantaranya yaitu: penghuni rumah tangga yang sudah lanjut usia; anggota keluarga atau masyarakat penghuni rumah 
yang bersikap cuek terhadap program G1R1J; anggota keluarga/penghuni rumah yang ditunjuk sebagai jumantik rumah sering lupa mencatat hasil pemantauan jentik yang telah dilakukan.

Hambatan tersebut diperburuk dengan temuan lainnya dari hasil wawancara adalah sikap pragmatis dari warga ketika ditemukan jentik di rumahnya, mengganggap bahwa di tempat tersebut (rumahnya) memang biasa ditemukan jentik. Hal ini menunjukkan kader sebagai ujung tombak pelaksanaan program G1R1J tidak dapat berdiri sendiri. Upaya kader memerlukan dukungan puskesmas sebagai stakeholder dan kerjasama lintas sektor dengan tokoh masyarakat di lingkungan wilayah kerja mereka seperti RT dan RW. Hal tersebut sejalan dengan hasil penelitian (Prastiani and Prasasti, 2018) yang menyebutkan bahwa puskesmas dan dinas kesehatan sebaiknya melakukan upaya penyuluhan secara rutin agar dapat meningkatkan pengetahuan masyarakat tentang DBD dan PSN.

Program pemberdayaan masyarakat ini keberlangsungannya terkait erat dengan rasa memiliki yang kuat dari masyarakat terhadap program itu sendiri. Peningkatan rasa memiliki terhadap G1R1J perlu dilakukan melalui kegiatan-kegiatan yang sifatnya lintas program dan melibatkan lintas sektor. Sosialisasi mengenai teknis pelaksanaan G1R1J merupakan salah satu cara untuk meningkatkan pengetahuan dan kesadaran masyarakat yang dapat berimbas pada rasa memiliki terhadap program G1R1J. Masih terdapat warga yang kurang tersosialisasi dengan program ini secara teknis pelaksanaan. Sosialisasi oleh petugas masih perlu ditingkatkan. Hal tersebut seperti yang dilaporkan Listyorini (2016) yang menyebutkan bahwa peran petugas itu signifikan dalam memengaruhi perilaku pemberantasan sarang nyamuk yang dilakukan masyarakat.

Limitasi dalam penelitian dengan pendekatan HBM ini tidak memperhitungkan sikap, keyakinan, atau faktor penentu seseorang yang menentukan penerimaan seseorang terhadap perilaku kesehatan. Hasil temuan dalam penelitian ini tidak dapat digeneralisir terhadap wilayah lain yang endemis DBD dalam implementasi G1R1J.

\section{KESIMPULAN DAN SARAN}

\section{Kesimpulan}

Pendekatan model HBM dalam melihat persepsi kader terhadap program Gerakan 1 Rumah 1 Jumantik
(G1R1J) di Kelurahan Pondok Betung Kota Tangerang Selatan Provinsi Banten ini dipengaruhi aspek pengetahuan dan motivasi. Persepsi risiko terkait penyakit (infeksi dengue) dan manfaat dari program G1R1J menjadi salah satu motivasi kader dalam menjalankan perannya. Kesenjangan pengetahuan, motivasi dan ketergantungan jumantik rumah kepada kader dalam melaksanakan PSN adalah sebagai penyebab belum optimalnya pelaksanaan G1R1J di Kelurahan Pondok Betung Kota Tangerang Selatan Provinsi Banten.

\section{Saran}

Rekomendasi yang dapat diberikan dari hasil penelitian ini adalah perlunya sosialisasi atau transfer ilmu mengenai program G1R1J secara intensif di tingkat keluarga dengan melibatkan stakeholder dan tokoh masyarakat setempat. Penyuluhan dan pemberdayaan yang tepat pada masyarakat mengenai upaya penurunan infeksi dengue terhadap keluarga perlu ditingkatkan. Pemberian tanggung jawab dan penghargaan pada jumantik rumah sebagai upaya membangun rasa memiliki terhadap program G1R1J. Perlunya dilakukan penelitian lebih lanjut terkait sosial budaya setempat, sehingga intervensi dengan pendekatan kearifan lokal diharapkan dapat diterima masyarakat dan lebih terjamin keberkelanjutannya.

\section{UCAPAN TERIMA KASIH}

Terima kasih kami sampaikan kepada:

- Kepala Loka Litbangkes Pangandaran yang telah mendukung dalam pelaksanaan penelitian ini,

- Kepala Dinas Kesehatan Kota Tangerang Selatan beserta jajaran staf terkait,

- Kepala puskesmas, pengelola program dan seluruh staf, serta masyarakat yang berperan sebagai informan dalam penelitian ini.

\section{DAFTAR PUSTAKA}

Astuti, E. P. and Yuliasih, Y. (2019) 'Pencegahan Kasus Dengue dengan Pemberdayaan Masyarakat "Community Empowerement"', in Suwandono, A. (ed.) Dengue Update, Menilik Perjalanan Dengue di Jawa Barat. Jakarta: LIPI Press, p. 368.

Attamimy, H. B. and Qomaruddin, M. B. (2018) 'Aplikasi Health Belief Model Pada Perilaku Pencegahan Demam Berdarah Dengue', Jurnal PROMKES, 5(2), p. 245. https://doi.org/10.20473/jpk.v5.i2.2017.245255. 
Brady, O. J. et al. (2012) 'Refining the Global Spatial Limits of Dengue Virus Transmission by Evidence-Based Consensus', PLoS Neglected Tropical Diseases, 6(8). https://doi.org/10.1371/journal.pntd.0001760.

Burke, A. J. (2015) An Investigation Of Intimate Partner Violence Perceptions In Nine Appalachian Ohio Counties: A Health Belief Model Approach. Kent State University.

Carpenter, C. J. (2010) 'A Meta-Analysis of the Effectiveness of Health Belief Model Variables in Predicting Behavior', Health Communication. Routledge, 25(8), pp. 661-669. https://doi.org/10.1080/10410236.201 0.521906 .

Chandren, J. R., Wong, L. P. and AbuBakar, S. (2015) 'Practices of dengue fever prevention and the associated factors among the Orang Asli in Peninsular Malaysia', PLoS Neglected Tropical Diseases, 9(8), pp. 1-17. https://doi.org/10.1371/journal.pntd.0003954.

Chepkemoi Ng'etich Mutulei, A. (2013) 'Factors Influencing the Uptake of Intermittent Preventive Treatment for Malaria in Pregnancy: Evidence from Bungoma East District, Kenya', American Journal of Public Health Research, 1(5), pp. 110-123. https://doi. org/10.12691/ajphr-1-5-2.

Dinas Kesehatan Provinsi Banten (2019) Profil Kesehatan Provinsi Banten 2017-2018.

Djafar, M. (2014) ‘Dampak Pengetahuan dan Sikap Terhadap Tindakan Kader Posyandu Tentang Pedoman Umum Gizi Seimbang (PUGS) Di Pondok Betung Pondok Aren.', IImiah Widya, Volume $2 \mathrm{~N}$.

Djuhaeni, H., Gondodiputro, S. and Suparman, R. (2010) 'Motivasi Kader Meningkatkan Keberhasilan Kegiatan Posyandu', Majalah Kedokteran Bandung, Volume 42.

HaldaneV, ChuahFLH, Srivastava A,SinghSR, Koh GCH,SengCK, et al. (2019) 'Community participation in health services development, implementation, and evaluation:A systematic review of empowerment, health,community, and process outcomes.', PLoS One., PLoSONE 14. Available at: https://doi.org/10.1371/journal.pone.0216112.

Kartini, P. R. and Martini, S. (2018) ‘Penyuluhan Kesehatan Rutin Puskesmas Untuk Mencegah Sekolah Dasar Dengan Kejadian Dbd Di Kota Madiun Tahun 2017', Journal of Pharmaceutical Science and Medical Research, 1(1), p. 12. https://doi.org/10.25273/ pharmed.v1i1.2292.

Kementerian Kesehatan Republik Indonesia (2016) Petunjuk Teknis Implementasi PSN 3 M - Plus Dengan Gerakan 1 Rumah 1 Jumantik.

Kementerian Kesehatan Republik Indonesia (2018) Profil Kesehatan Indonesia Tahun 2010 - 2017.

Li Liu et al. (2016) 'Use of a knowledge-attitudebehavioureducation programme forChinese adults undergoingmaintenance haemodialysis:Randomized controlled trial', Journal of International Medical Research, Vol. 44(3).

Listyorini, P. I. (2016) 'Faktor-Faktor Yang Memengaruhi Perilaku Pemberantasan Sarang Nyamuk (PSN) Pada Masyarakat Karangjati Kabupaten Blora', Journal INFOKES, 6(1), pp. 6-15.

Prasetyowati, H. and Tim (2019) Laporan Penelitian 'Riset Implementasi Model Juru Pembasmi Jentik (Jurbastik) dalam Penanggulangan DBD Provinsi Jawa Barat dan Banten'. Pangandaran.

Prastiani, I. and Prasasti, C. I. (2018) 'Hubungan Suhu Udara, Kepadatan Hunian, Pengetahuan Dan Sikap Dengan Kepadatan Jentik Di Kecamatan Gunung Anyar, Kota Surabaya', Jurnal Kesehatan Lingkungan. https://doi.org/10.20473/jkl.v9i1.2017.1-10.

Purnama, S. G., Satoto, T. B. and Prabandari, Y. (2013) 'Pengetahuan, Sikap dan Perilaku Pemberantasan Sarang Nyamuk Terhadap Infeksi Dengue di Kecamatan Denpasar Selatan, Kota Denpasar, Bali.', Arc. Com. Health, 2(1), pp. 20-27.

Rasjid, A., Yudhastuti, R. and Notobroto, H. B. (2016) 'Relationship of environmental condition, container and behavior with the existence of Aedes aegypti mosquito larvae in an endemic area of dengue hemorrhagic fever, Makassar', Pakistan Journal of Nutrition. https://doi.org/10.3923/pjn.2016.295.298.

Rosenstock, I. M. (1974) 'The Health Belief Model and Preventive Health Behavior', Health Education Monographs. SAGE Publications, 2(4), pp. 354-386. https://doi.org/10.1177/109019817400200405.

Rubin, H. J. and Rubin, I. (2012) Qualitative interviewing : the art of hearing data. Thousand Oaks, Calif.: SAGE.

Sansiritaweesook G, K. M. (2015) 'Development of the Model for Local Drowning Surveillance System in Northeastern Thailand.', J Med Assoc Thai., 98 Suppl 6.

Selviana, S. and Suwarni, L. (2019) 'Efektivitas Model Promosi Kesehatan Melalui Media Video Implementasi G1R1J Dalam Meningkatkan Angka Bebas Jentik', Jurnal IImiah Ilmu Kesehatan: Wawasan Kesehatan, 5(2), pp. 143-149. https://doi.org/10.33485/jiik-wk. v5i2.116.

Siddiqui, T. R. et al. (2016) 'Use of the Health Belief Model for the Assessment of Public Knowledge and Household Preventive Practices in Karachi, Pakistan, a Dengue-Endemic City', PLoS Neglected Tropical Diseases, 10(11). https://doi.org/10.1371/journal. pntd.0005129.

WHO. (2017) 'Dengue and severe dengue, Factsheet117: World Health Organization', Factsheet117. Available at: availablefrom:http://www.who.int/mediacentre/ factsheets/fs117/en/. 